\title{
Wstęp
}

\section{Opiekuńcza utopia}

Przemysław Czapliński

TEKSTY DRUGIE 2021, NR 1, S. 7-18

DOI: 10.18318/td.2021.1.1 | ORCID: 0000-0002-4805-6471

„[...] pożyć - najlepiej jak można, skoro jeszcze można"

Ewa Guderian-Czaplińska'

D ierwsze teoretyczne powiązania „medycyny" $z_{\text {"narracjami” }}$ pojawiły się na przełomie lat 80. i 9o. XX wieku. Badacze, czasem klinicyści, kiedy indziej praktycy leczenia wskazywali na pożytki, jakie mogą płynąć z przyjęcia przez lekarza postawy czytelnika albo opowiadacza. Przekonywano zatem, że lekarz w ramach poszerzania własnych umiejętności może potraktować tekst literacki jako zadanie diagnostyczne. Bądź że powinien znacznie obszerniej (choć spójnie) wyjaśnić pacjentowi jego/jej chorobę, możliwości leczenia i późniejsze skutki. Był to, o czym warto pamiętać, okres dominacji tzw. medycyny opartej na faktach. Dość nieoczekiwanie tedy, w zenicie data-based medicine, jako konieczne uzupełnienie danych wprowadzono narrację. Nie jako alternatywę dla faktów, lecz jako metodę ich łączenia.

Na przełomie pierwszej i drugiej dekady XXI wieku istniało już kilkanaście definicji medycyny narracyjnej. Jeśli wczesne ujęcia

\author{
Przemysław \\ Czapliński - historyk \\ literatury XX i XXI \\ wieku, eseista, tłu- \\ macz; współtwórca \\ Zakładu Antropologii \\ Literatury (UAM \\ Poznań). Ostatnie \\ publikacje: Polska \\ do wymiany (2009), \\ Resztki nowoczesno- \\ ści (2011), Literatura \\ ustna (2011), Kamp. \\ Antologia przekładów \\ (współredaktor A. Mi- \\ zerka, 2013), Poetyka \\ migracji (wespół \\ z Renatą Makarską \\ i Martą Tomczok, \\ 2013), Poruszona \\ mapa (2016).
}

1 E. Guderian-Czaplińska Trojanki. Dziesięć prywatnych rad dla początkujących w chemioterapii potrójnie ujemnego raka piersi, Media Rodzina, Poznań 2020, S. 136. 
wskazywały na narrację jako sztukę wrażliwości i akcentowały rolę empatii w kontakcie lekarza z pacjentem, to definicje późniejsze zostały znacząco poszerzone. Rita Charon w książce Narrative medicine. Honoring the stories of illness (2006), uznawanej za jedno z fundamentalnych dzieł omawianej dyscypliny, stwierdziła, że jest to „medycyna stosująca w praktyce kompetencję narracyjną do rozpoznawania, przyswajania, interpretowania i emocjonalnego otwierania się na opowieści o chorobach"2. W słowniku medycznym z 2012 roku odpowiednie hasło mówi, że jest to „nowa dyscyplina kliniczna, która bada narracje pacjentów jako płaszczyznę pomocną w ulepszaniu interakcji między lekarzami, pielęgniarkami, pracownikami socjalnymi, terapeutami i innymi opiekunami"3. W definicji sformułowanej w 2014 roku przez zespół złożony z międzynarodowych ekspertów czytamy: „Medycyna narracyjna jest podstawowym narzędziem do przyswajania, rozumienia i integrowania różnych punktów widzenia wszystkich uczestników odgrywających [zróżnicowane] role w doświadczaniu choroby"4.

Prawdą jest, że ceną za pojemność definicji okazuje się niedostatek precyzji trudno przecież na podstawie powyższych enumeracji dokładnie określić zestaw umiejętności, jakie powinien posiąść personel medyczny. Rozrzutność pozwala jednak zobaczyć ewolucję medycyny narracyjnej - od kierowanych pod adresem lekarza postulatów uważnego słuchania do projektu integrowania wszystkich osób uczestniczących w doświadczaniu choroby. Początkowa koncentracja na lekarzu i pacjencie rozszerzyła się do koncepcji przebudowy systemu opieki medycznej. Medycyna narracyjna to utopia.

Niektóre punkty tej utopii - chorego należy słuchać, lekarz powinien wyjaśniać choremu proces leczenia - zdają się proste i oczywiste. Jeśli trzeba utopii, by odzyskać rzeczy proste, to znaczy, że całość funkcjonuje przeciw oczywistościom.

\section{Medycyna jako system}

Medycyna narracyjna powstała w konkretnym kontekście historycznym, na który złożyły się czynniki i procesy stymulujące przebudzenie narracyjne.

Uwarunkowaniem negatywnym była autonomia osiągnięta przez medycynę oficjalną. W pierwszej połowie XX wieku państwa nowoczesne walczyły o monopolizację

2 R. Charon Narrative medicine. Honoring the stories of illness, Oxford University Press, Oxford-New York 2006, s. vii.

3 J.C. Segen The Dictionary of modern medicine, Farlex, 2012, cyt. za: https://medical-dictionary.thefreedictionary.com/narrative+medicine (1.02.2021).

4 Cyt. za: G. Zaharias What is narrative-based medicine , "Canadian Family Physician” 2018 no. 64 (3), s. 177. 
nadzoru nad medycyną. Walka zakończyła się pełnym sukcesem - w drugiej połowie tegoż stulecia państwo stało się wyłącznym kontrolerem opieki zdrowotnej. Monopolizacja polegała na (i dokonała się dzięki) zdyscyplinowaniu wszystkich aspektów związanych z leczeniem. Nauczanie i zatwierdzanie uprawnień lekarskich, współpraca uczelni ze szpitalami i placówkami naukowymi, profilaktyka, opieka ogólna i specjalistyczna - wszystko to zostało ujęte w protokoły. Również kontakt z pacjentem. Opracowano liczące kilka stron i kilkadziesiąt pytań szczegółowe ankiety służące wydobyciu informacji istotnych dla procesu leczenia i zapobiegające ewentualnym pozwom sądowym. Protokoły nie pozbawiały pacjenta prawa do głosu. Przekształcały go w bazę danych. Prawna i instytucjonalna, kompetencyjna i decyzyjna przewaga lekarza nad pacjentem została tak daleko posunięta, że lekarz - w odpowiednich okolicznościach - mógł z pacjentem zrobić prawie wszystko. Nawet to „prawie” zbyt często oznaczało zbyt wiele.

Istniejące wewnątrz systemu medycznego mechanizmy kontrolne i korekcyjne okazały się przy tym niedostateczne lub stronnicze, nie mogły więc powstrzymać złych skutków takiej przewagi. System był bowiem tylko po części wytworem osiągnięć samej medycyny, w znacznej zaś mierze zawdzięczał pozycję wsparciu ze strony państwa i prawa. To usytuowanie sprawiało, że lekarze w XX wieku uczestniczyli w rozmaitych (niejednokrotnie zbrodniczych) eksperymentach eugenicznych, segregacyjnych, selekcyjnych czy izolacyjnych - i to nie tylko w warunkach państwa totalitarnego ${ }^{5}$, lecz także w czasach pokoju ${ }^{6}$. Świadomość ciągłości przemocy medycyny nad pacjentem jest wiedzą powszechną - trudno byłoby w dziejach znaleźć pacjenta bez złych doświadczeń z lekarzem. Niemniej prawo do nadużywania autorytetu przysługiwało lekarzom w ramach, nazwijmy to tak, poszerzonego kontraktu Hipokratesa, czyli niepisanej umowy społecznej, zakładającej, że lekarz, nawet okrutny, działa na rzecz dobra pacjenta. Tymczasem na początku lat 6o. zaczęły się ukazywać książki, które podważyły ten punkt umowy społecznej.

W 1961 roku Michel Foucault publikuje Historię szaleństwa w dobie klasycyzmu, w której przedstawia historyczną translację struktur wykluczania: w XV-wiecznej Europie miejsce trądu, wraz ze stopniowym zanikaniem tej choroby, zajęło szaleństwo; początkowe wyrzucanie szaleńców poza granice społeczności ustąpiło w kolejnych stuleciach praktykom zamykania, a XIX-wieczne wynalezienie chorób psychicznych

5 Zob. E. Klee Auschwitz. Medycyna III Rzeszy i jej ofiary, przeł. E. Kalinowska-Styczeń, Universitas, Kraków 2005.

6 O szwedzkim projekcie eugenicznym wdrażanym wiele lat po II wojnie światowej - zob. M. Zaremba Bielawski Higieniści.Z dziejów eugeniki, przeł. W. Chudoba, Czarne, Wołowiec 2011. To samo (z większym okrucieństwem) w Australii - zob. M. Marczewski Niewidzialni, Czarne, Wołowiec 2012. O polityce rasowej Kanady wobec mieszkańców rdzennych - zob. J. Gierak-Onoszko 27 śmierci Toby'ego Obeda, Dowody na Istnienie - Fundacja Instytutu Reportażu, Warszawa 2019. 
jako przypadłości podlegających leczeniu pogłębiło „wielkie uwięzienie”. Praca Foucaulta stała się jedną ze sztandarowych książek antypsychiatrii w Europie. Z kolei dla społeczeństwa amerykańskiego wstrząsem okazały się dwa inne dzieła: Lot nad kukułczym gniazdem Kena Keseya (1961) i zbiór esejów Ervinga Goffmana Instytucje totalne (1961)․ Pierwsza książka w ujęciu fabularnym przedstawiała historię zniszczenia zdrowego człowieka w szpitalu psychiatrycznym, druga omawiała warunki i skutki sformalizowania życia dużej grupy ludzi w jednym miejscu. Do warunków tych Goffman zaliczył: uznanie interesu instytucji za nadrzędny, podporządkowanie wszystkich czynności regulaminowi i pozbawienie osób „osadzonych” jednostkowej tożsamości. Na podstawie charakterystyki autor tworzył długi szereg, w którym oddział zakaźny i szpital psychiatryczny stawały obok innych instytucji totalnych - domów opieki i domów dla seniorów, więzień, obozów koncentracyjnych i obozów pracy, szkół z internatem, koszar, klasztorów i seminariów duchownych Opublikowana w 1975 roku kolejna książka Foucaulta, Nadzorować i karać, wzmacniała rozpoznania Goffmana, osadzała je w porządku nowoczesności i przyznawała rację sytuowaniu więzienia obok szpitala. Strukturalne podobieństwo tych instytucji podważało punkt kontraktu Hipokratesa mówiący o przemocy jako nieistotnym lub niekiedy koniecznym warunku leczenia - celem „osadzenia” okazywało się utrzymywanie nadzoru. W kontekście rozważań Goffmana i Foucaulta charakter totalny przenosił się z konkretnych placówek medycznych na system medyczny jako taki.

Wpływu tych dzieł na medycynę nie należy ani przeceniać, ani lekceważyć, tym bardziej że nie były osamotnione. W latach 6o. badania nad zamkniętymi oddziałami szpitalnymi coraz częściej dotyczyły „stosunków władzy”, co prowadziło do stosowania określeń „totalitaryzm” czy "autorytaryzm”9 w odniesieniu do ośrodków leczniczych. Powieść Keseya upowszechniła więc pewien typ podejrzliwości, a ekranizacja Lotu nad kukułczym gniazdem dokonana przez Miloša Formana (1975) ${ }^{10}$ rozkołysała zbiorowe emocje. Dzieło nie przekonywało jednak, że każdy szpital psychiatryczny jest

7 Wydanie polskie: E. Goffman Instytucje totalne. O pacjentach szpitali psychiatrycznych i mieszkańcach innych instytucji totalnych, przeł. ). Łaszcz, Gdańskie Wydawnictwo Psychologiczne, Gdańsk 2011.

8 Wybitnym i wstrząsającym przykładem zastosowania tej koncepcji w piśmiennictwie polskim jest reportaż Justyny Kopińskiej Czy Bóg wybaczy siostrze Bernadetcie? (Świat Książki, Warszawa 2015), ujawniający metody dyscyplinowania dzieci w ośrodku wychowawczym prowadzonym przez Siostry Miłosierdzia św. Karola Boromeusza w Zabrzu.

9 Zob. np. J.H. Williams, H.M. Williams Attitudes toward mental illness, anomia and authoritarianism among state hospital nursing students and attendants, "Mental Hygiene" 1961 no. 45, s. 418-424.

10 Zob. G. Domino Impact of the film, "One flew over the cuckoo's nes," on attitudes towards mental illness. „Psychological Reports” 1983 no. 1 (53), s. 179-182. 
więzieniem o zaostrzonym rygorze, wskazywało natomiast, jakie warunki są odpowiedzialne za takie przekształcenie. Po filmie Formana debata nad „psychiatrykami” wylała się poza granice profesjonalne i wróciła do instytucji medycznych falą wsteczną": wzrost nieufności utrudniał pracę personelowi szpitali12 ${ }^{\mathbf{2}}$ a ponadto kierował strumień pieniędzy i pacjentów ku tym placówkom, które cieszyły się opinią otwartych czy przyjaznych. Zaczęto się domagać kontroli oddziałów zamkniętych i weryfikacji procedur ubezwłasnowolnienia. Z badań prowadzonych wśród studentów medycyny wynikało, że defensywna postawa pacjenta jest postrzegana jako przeszkoda w leczeniu. Autonomia uzyskana w XX wieku przez medycynę - konieczna z punktu widzenia zdrowia populacyjnego - okazywała się przeciwskuteczna. Efektywność leczenia wymagała dopuszczenia pacjenta do głosu.

Sprawa nabierała tym większej konieczności, że błędne leczenie wynikające z niedostatecznej uważności w słuchaniu pacjentów kończyło się coraz częściej procesami sądowymi. Postulat komunikacji z chorym formułowano więc nie tylko dla lepszego diagnozowania, lecz także w celach samoobronnych, tym bardziej że hegemonię medycyny opartej na danych starano się osłabić przez ustalenie praw pacjenta.

Inicjatywy związane ze wzmocnieniem prawnej pozycji chorego - pojawiające się w kulturze europejskiej co najmniej od XIX wieku - przybrały kształt konkretnych regulacji dopiero u schyłku wieku XX: w 1984 roku powstała Karta Praw Pacjenta wydana z inicjatywy Parlamentu Europejskiego Wspólnoty Europejskiej³, w roku 1994 - Deklaracja Promocji Praw Pacjenta w Europie, a w roku 2008 - Europejska Karta Praw Pacjenta ${ }^{\mathbf{1 4}}$. Wśród kilkunastu punktów znalazły się: prawo do informacji, prawo do przedstawienia lekarzowi swojego zdania, prawo do wyrażenia zgody, prawo dostępu do dokumentacji medycznej oraz prawo do zgłaszania sprzeciwu wobec opinii albo orzeczenia lekarza. W świetle medycyny autonomicznej prawa te wyglądały na rewolucję. Nie chodziło jednak o obalenie władzy lekarskiej, lecz o stworzenie warunków współpracy. Dla warunków tych kluczowe znaczenie miało uznanie pacjenta za aktywnego współuczestnika leczenia.

I ostatni składnik kontekstu - Internet. Niemałą, choć trudną do oszacowania, rolę w upodmiotowieniu chorego odegrała narracyjna potęga nowego medium. Narracyjna

11 Maria Giulia Marini w książce Bridging the gap between evidence-based medicine and medical humanities (Springer, 2016) poświęciła rozdział filmom skupiającym się na chorobach (s. 71-80).

H. Bengtsson Do people dare to seek psychiatric care after having seen the film „One flew over the cuckoo's nest"? , "Lakartidningen" 1976 no. 73 (39), s. 3181-3184.

13 Zob. D. Karkowska Prawa pacjenta, Dom Wydawniczy ABC, Warszawa 2004.

146 listopada 2008 ustawę o prawach pacjenta i Rzeczniku Praw Pacjenta (Dz.U. z 2009 r. nr 52, poz. 417, z późn. zm.) przyjął także polski sejm. 
i ewaluacyjna. Rozwijający się od przełomu lat 8o. i 9o. XX wieku Internet pozwalał pacjentom i ich rodzinom publicznie oceniać lekarzy, szpitale, personel15. Oceny te pojawiały się w dłuższych lub krótszych opowieściach, a opowieści konkretyzowały doświadczenie choroby, opisywały stan psychiczno-emocjonalny, jaki temu towarzyszył, przedstawiały etapy leczenia i przebieg rehabilitacji. Narracje nie były skierowane do lekarzy, choć mogły mieć charakter apelu, protestu, oskarżenia (a także, oczywiście i niestety, pomówienia). Niektóre z nich, wcale liczne, zawierały sporą dawkę wiedzy medycznej, inne były fachowości pozbawione. Z narracji konkretnych i niekonkretnych, sprawiedliwych i stronniczych, pochwalnych i oskarżycielskich wynikało jednak, że pacjent chce mówić i że potrafi określić własne nastawienie do leczenia. Narracja okazywała się sposobem osiągania samowiedzy i czynnikiem procesu zdrowienia.

Trzy wymienione procesy - rewizja nadmiernej autonomii systemu medycznego (przeszkadzającej w skutecznym leczeniu), ruch na rzecz praw pacjenta, napór opowieści o chorowaniu dochodzący spoza obszaru opieki zdrowotnej - współtworzą kontekst dla pojawienia się medycyny narracyjnej.

\section{Kręgi narracyjne}

Medycyna narracyjna rodzi się z dobrych i złych doświadczeń medycyny. Ich owocnym rezultatem stało się założenie, że aktywność narracyjna pacjenta jest czynnikiem pomocnym w procesie leczenia. Istota medycyny narracyjnej polega jednak nie na tym, by pacjent się wygadał, lecz na tym, by całą medycynę ukształtować jako środowisko multinarracyjne, w którym osobne opowieści będą łączyć się i wspieraćc ${ }^{16}$.Zamiast układu konsekutywnego - najpierw opowiada pacjent, potem doktor - należy stworzyć system nakładających się na siebie i wzajemnie wzmacniających kręgów narracyjnych.

Pierwszy krąg powstaje podczas spotkań diagnostycznych. W kręgu tym narracja pacjenta jest nie tyle "opowieścią o chorobie", ile "chorą opowieścią" - jest formą doświadczania i wyrażania choroby, jednostkową ekspresją zakłóconego zdrowia. Narracja ta stwarza podstawę narodzin empatii oraz - powiązanego z empatią - porozumienia między lekarzem a pacjentem. W przestrzeni komunikacyjnej wypracowanej dla

15 Dziś dodać do tego należy całkiem poważną konkurencję kompetencyjną, którą stwarzają niepoliczalne (i zróżnicowane pod względem wiarygodności) medyczne portale doradcze, e-czasopisma popularyzatorskie z zakresu leczenia, blogi, fora dyskusyjne i inne formy służące wymianie doświadczeń, zasięganiu rady, a nawet uzyskiwaniu wstępnych diagnoz. Pandemia - jako czas, który zamknął ludzi w domach i utrudnił dostęp do placówek medycznych - znacząco wzmocnił kompetencyjną rolę Internetu. 
opowiadającego pacjenta i słuchającego lekarza powstają dogodne warunki do określenia sensu. Właśnie sensu, a nie tylko "diagnozy", ponieważ pacjent pod wpływem choroby (zwłaszcza ciężkiej) zmienia narrację o życiu; nie ma gotowej redefinicji, nie ułożył sobie wszystkiego na nowo - wie, że został zraniony przez chorobę albo uświadomił sobie, że jest podatny na zranienie. Jego słowa mogą podsunąć lekarzowi pomocną kategorię bądź wskazówki analityczne.

Drugi krąg wiąże się z leczeniem. W kręgu tym znaczenie narracji pacjenta rośnie, ponieważ już sama narracja odgrywa rolę terapeutyczną czy paliatywną - akt mówienia, wypowiadania swoich lęków i nadziei jest częścią procesu leczenia. Ponadto chory poprzez swoją opowieść nie pozwala lekarzowi ograniczyć leczenia do jednego miejsca w ciele czy na ciele, do jednego problemu czy jednego źródła. Człowieka ciężko chorego boli całe „ja" ${ }^{\prime \prime}$. Jego słowa kierują terapię ku ujęciu całościowemu - ku uwzględnieniu tych partii ciała bądź tych funkcji cielesnych, których wzmocnienie może zwrotnie poprawić kondycję całościową. Z poszerzonej opowieści wyłonić się może podpowiedź dodatkowych działań terapeutycznych - zajęć, aktywności, ćwiczeń, leków.

Krąg trzeci, edukacyjny, zagarnia wszystkich - studentów, lekarzy, pacjentów, pielęgniarzy, specjalistów od rehabilitacji czy opieki paliatywnej, pracowników pomocniczych i administracyjnych. Wszyscy mogą się od siebie czegoś dowiedzieć za pośrednictwem narracji, ponieważ narracje są zakorzenione w konkretnym doświadczeniu, podane $w$ formie łatwiejszej do zapamiętania i zachęcającej do samodzielnego myślenia nad różnymi aspektami leczenia. Taki pofałdowany krąg powinien być przede wszystkim sferą praktykowania egalitaryzmu komunikacyjnego - wzajemności, otwartości, życzliwości. Z punktu widzenia praktyki powinien natomiast być sferą najintensywniejszej wymiany narracji - uzupełniania, korygowania, konkretyzowania i ewentualnego uogólniania doświadczeń.

Wreszcie krąg czwarty - naukowy. Tu narracje pomagają ustalić program badawczy nastawiony na pacjenta. Opowieść chorego może zakwestionować postawioną diagnozę albo podważyć sposób postępowania wobec całej klasy chorych (jak w przypadku zawału serca - traktowanego poważnie u mężczyzn i lekceważonego u kobiet $\left.{ }^{18}\right)$. Może też zmienić metodę zdobywania wiedzy o dolegliwości, kierując ku innym pytaniom albo ku połączeniu pytań z konkretnym badaniem. Finalnie narracja pacjenta może pomóc w postawieniu nowej hipotezy (jak w przypadku tajemniczych

17 Nawiązuję tu do eseju Tadeusza Sławka "Ja bolę." Boleść i terapia w tomie zbiorowym Fragmenty dyskursu maladycznego (red. Maciej Ganczar, Ireneusz Gielata, Monika Ładoń. Fundacja Terytoria Książki, Gdańsk 2019).

18 Zob. J. Wojteczek Choroby serca mają płeć, serwis Zdrowie, $18 \mathrm{VII}$ 2018, https://zdrowie.pap.pl/byc-zdrowym/choroby-serca-maja-plec (12.01.2021). 
samobójstw wśród sportowców uprawiających amerykański futbo|ำ). Narracje przebiegają tu więc od chorego do lekarza czy badacza i z powrotem do pacjenta lub personelu - nie w linii prostej, lecz po okręgach.

W każdym z tych kręgów powinni móc uczestniczyć członkowie rodzin, przyjaciele, sąsiedzi, znajomi z pracy. Takie poszerzenie uświadamia dość istotną różnicę: medycyną autonomiczną rządzi geometria linii prostej, która łącząc dwa punkty (pacjent - lekarz) wyznacza najważniejszą oś; pacjent uzyskuje pomoc ze strony lekarza niejako za cenę wyizolowania ze społeczeństwa. Medycyna narracyjna usiłuje zmienić tę geometrię w układ wielookręgowy. Celem nie jest więc wprowadzenie nowej praktyki leczenia oprócz wielu innych, lecz przekształcenie medycyny jako systemu opieki. Rolę motoru zmian powinna odegrać właśnie medycyna narracyjna ${ }^{\mathbf{2 0}}$.

\section{"You'll never walk alone"}

Co w tym niezwykłym przedsięwzięciu łączy medycynę z humanistyką? Ból. Ból budzi strach, rozgniata sens. Czyni osobnym nawet wśród bliskich. Domaga się nazwania, ale wydobywa z ciała krzyk, nie słowa. Popycha do komunikacji i ją zakłóca.

Od tego właśnie doświadczenia - a także towarzyszących temu bezradności i aktywności - zaczyna się spotkanie medycyny z humanistyką. Najrozleglejszą płaszczyznę wspólną tworzą teksty literackie i metodologie. Początki medycyny narracyjnej - przy całej względności wyznaczania takiego momentu - polegały na zestawianiu lektury wybranego dzieła literackiego z własnym doświadczeniem pracy lekarskiej. Jednak wiersze Johna Donne'a, proza Henry'ego Jamesa, Gustava Flauberta czy Fiodora Dostojewskiego, Frankenstein Mary Shelley, Czarodziejska góra Tomasza Manna czy inne teksty poddawane analizie medycznej służyły nie tyle zdiagnozowaniu konkretnej choroby pacjenta/bohatera, ile unaocznieniu złożoności opowieści. Gęstość narracji „pacjenta" prowadziła do wniosku o konieczności zmiany postawy interpretacyjnej. Wanalizach lekarz musiał więc cofnąć się do etapu sprzed studiów medycznych i zadać sobie pytanie dotyczące semiotyki opowieści pacjenta. Komplikacje owej opowieści pomagały w dekonstruowaniu metody lekarskiej i powtórnym jej konstruowaniu uwzględniającym literaturoznawcze inspiracje.

W pierwszej dekadzie naszego stulecia podstawową metodologią medycyny narracyjnej stało się „bliskie czytanie." Przemawiały za tym zarówno tradycje anglosaskie, przyswojone przez lekarzy w trakcie nauki na etapie licealnym, jak i kluczowe dla close

19 Zob. B. Omalu Truth doesn't have a side: my alarming discovery about the danger of contact sports (Zondervan, Grand Rapids, MI 2017). 
reading założenia: skupienie na leksykalnych i składniowych mikroelementach dzieła, uznanie tekstu za zamkniętą całość dającą się wyizolować z kontekstu, wiara w stabilność wniosków interpretacyjnych. Tę metodę, ograniczaną przez wymogi etyczne, przekładano - jak omawia to artykuł Marty Chojnackiej-Kuraś poświęcony koncepcji Rity Charon - na edukację. Metoda indywidualnego obcowania z tekstem zaczęła służyć nauczaniu kompetencji narracyjnej.

Metodologie wykorzystywane w obrębie medycyny narracyjnej są coraz bardziej zróżnicowane i zniuansowane. Nie sposób tej wielości przedstawić, dlatego w niniejszym numerze "TD" teksty Rity Charon i Angeli Wood prezentowane są jako skrót z historycznego rozwoju i odsłonięcie krytycznej świadomości. Tekst Hanny Serkowskiej, polemiczny wobec eseju Susan Sontag Choroba jako metafora (1978), uświadamia z kolei, że medycyna narracyjna musi liczyć się z uzusem językowym, z terminologią porządkującą episteme lekarza, z metaforami dyscyplinującymi społeczeństwo lub stygmatyzującymi chorego. Bliskie czytanie służy więc dzisiejszym badaczom medycyny narracyjnej do tworzenia trwałych modeli edukacyjnych i zarazem rodzi w nich nieufność wobec narracji i języka.

Medycyna narracyjna nie jest jednak genetycznie uzależniona od metodologii literaturoznawczych spod znaku formalistycznego. Dowodzą tego przypadki lekarzy, którzy wymyślili metodę bliską medycynie narracyjnej na długo przed jej zaistnieniem albo uprawiali ją równolegle, lecz dzięki innym inspiracjom. Pod tym względem każda lokalna kultura medyczna ma do odkrycia własne tradycje. W wypadku polskich dokonań przywołuje się trzy postaci.

Pierwsza z nich to Antoni Kępiński - reformator polskiej psychiatrii, jeden z prekursorów badań nad traumą ${ }^{21}$. Najważniejsze dzieła stworzył w latach 70. (m.in. Psychopatologia nerwic, Lęk, Schizofrenia). Kładł silny nacisk na pozamerytoryczne aspekty osobowości psychoterapeuty. Uznawał, że w kontakcie z pacjentem wiedza medyczna jest konieczna, lecz niewystarczająca. Relacja lekarz-pacjent według Kępińskiego musi mieć charakter emocjonalny, co oznacza, że terapeuta, zamiast zasłaniać się przed pacjentem swoją wiedzą, powinien empatycznie się na niego otworzyć. Poznanie chorego (1978), ostatnia i wydana już pośmiertnie jego książka, mówiło właśnie o tym, że lekarz musi przekierować swoją uwagę z choroby na człowieka, który jest chory. Kluczowe pojęcia metody Kępińskiego - więź, emocjonalne otwarcie, zaufanie do wiedzy pacjenta, dialog - należą dziś do podstawowego słownika medycyny narracyjnej.

Postać druga to Andrzej Szczeklik. W kontekście medycyny narracyjnej jego eseistykę w niniejszym numerze "TD” omawia Dorota Samborska-Kukuć. Szczeklik

21 Kępiński był więźniem obozu koncentracyjnego Miranda de Ebro; długotrwałość skutków tamtego doświadczenia opisał w Refleksjach oświęcimskich (1968). 
- naukowiec, praktykujący lekarz (kardiologia i pulmonologia) - stworzył luźny tryptyk z zakresu filozofii medycyny: Katharsis. O uzdrowicielskiej mocy natury i sztuki (2002), Kore. O chorych, chorobach i poszukiwaniu duszy medycyny (2007), Nieśmiertelność. Prometejski sen medycyny (2012). W esejach ujmował medycynę w ramy silnych opozycji: katharsis i biochemia, „źrenica duszy” i zaawansowane badania wnętrza ciała, sny o nieśmiertelności i degeneracje neuronowe. Podkreślanie rozbieżnych celów i metod medycznych pozwalało Szczeklikowi wyeksponować wartości, które uznawał za jedyne trwałe dziedzictwo medycyny - troskę o dobro pacjenta i konieczną niepewność lekarza. Między troską a niepewnością sytuował zaś kontakt z chorym, słuchanie, emocjonalne otwarcie lekarza. Rezultatem spotkania lekarza z chorym jest diagnozowanie, które Szczeklik określał jako sztukę interpretacji symptomów i narracji.

Do powyższych dwóch postaci dodać można - coraz częściej przywoływaną w kontekście medycyny narracyjnej - Małgorzatę Baranowską, historyczkę literatury, poetkę, pisarkę. Baranowska przez trzydzieści lat żyła z ciężką chorobą (toczeń). Zmagania z chorobą opisała w książce To jest wasze życie. Być sobq w chorobie przewlekłej (1994). Nakłaniała w niej do patrzenia na chorobę jako radykalnie zmienione, ale w dalszym ciągu własne i całościowe życie. Wymaga ono stworzenia od podstaw codzienności: „Bo czym jest choroba przewlekła i walka z nią? To przede wszystkim codzienność. Nic z romantyzmu, po prostu żmudne codzienne bytowanie ${ }^{\mathbf{2 2 2}^{2}}$. W zgodzie z tym myśleniem Łucja Lange w artykule Tożsamość i niepewność zinterpretowała egzystencję osób po przeszczepach płuc - nie jako wersję okrojoną, lecz jako życie polegające na testowaniu możliwości życia.

Szukanie rodzimych tradycji i lokalnych wariantów pozwala na ostrożne stwierdzenie, że specjalnością polską - przynajmniej jeśli wziąć pod uwagę ostatnie lata - są narracje maladyczne i dyskurs maladyczny. Określenia te odsyłają, odpowiednio, do zapisów chorób oraz do badań nad kulturowymi (prawnymi, medycznymi, medialnymi, literackimi) reprezentacjami chorób ${ }^{23}$. Choroba jest wyzwaniem ekonomicznym, politycznym, medycznym, ma swoją narrację potoczną i naukową, angażuje jednostkę i mikrospołeczność, toteż dyskurs maladyczny jest wielodyscyplinowy. Punktem wyjścia dla tego dyskursu jest uznanie choroby za doświadczenie ponadgatunkowe i zarazem indywidualizujące (nie istnieje gatunek wolny od chorób, ale choroba jest zawsze "czyjaś"); choroba ma również charakter totalizujący (ból nie daje się oddzielić od ciała czy od „ja", zagarnia jednostkę w całości), a zarazem osmotyczny. Choroba rozlewa się po całym ciele, zmienia doświadczanie siebie i postrzeganie świata, a w wypadku

M. Baranowska To jest wasze życie. Być sobq w chorobie przewlekłej, Znak, Kraków 1994, s. 12.

23 Zob. M. Szubert Dyskurs maladyczny - perspektywy badawcze, w: Fragmenty dyskursu maladycznego. 
zapisów - odkształca tkankę pisanych tekstów. Ta równoczesność podobieństwa chorych i osobności każdego chorego, totalności choroby i jej osmotycznego działania staje się wyzwaniem dla dyskursu maladycznego; praktyka ta musi być uważna wobec języka na krańcach komunikacji i empatyczna; powinna łączyć zapis cielesności doświadczenia z materialnością zapisu i przekraczać podziały gatunkowe. W piśmiennictwie polskim w ciągu dwóch ostatnich dekad powstało kilkadziesiąt narracji osobistych poświęconych ciężkim przypadłościom oraz równie wiele - komplementarnie usytuowanych - analiz dyskursu maladycznego. Wprowadzeniem w ten dyskurs są prezentowane w niniejszym zeszycie "TD" recenzje. Hanna Serkowska ujmuje łącznie w swoim omówieniu książkę Małgorzaty Okupnik W niewoli ciała. Doświadczenie utraty zdrowia i jego reprezentacje (2018) oraz monografię Moniki Ładoń Choroba jako literatura.Studia maladyczne (2019), omawiając analizy indywidualnych stylów chorowania. Podwójne zestawienie zaproponowała także Agnieszka Kwiatkowska - w recenzji obejmującej Fragmenty dyskursu maladycznego (pod redakcją Macieja Ganczara, Ireneusza Gielata i Moniki Ładoń, 2020) oraz książkę Medycyna narracyjna. Opowieści o doświadczeniu choroby w perspektywie medycznej i humanistycznej (pod redakcją Marty Chojnackiej-Kuraś, 2019) autorka podkreśla analizowaną przez badaczy bolesną rozpiętość (od somatyczności po mistycyzm) doświadczenia choroby i omawia wpływ totalności bólu na praktykę interpretacyjną. W osobnej recenzji Elżbieta Kiślak omawia antologię Medycyna (pod redakcją i z obszernym wstępem Grzegorza Marca, 2018), odsłaniającą wielość "medycyn" praktykowanych w wieku XIX ${ }^{24}$.

Dzięki tym książkom, odsyłającym do dziesiątków dzieł literackich, możemy się zorientować w zaawansowaniu rodzimej refleksji nad chorobami i ich kulturowym usytuowaniem oraz w brakującym dopełnieniu instytucjonalnym. Dopiero wszystkie te aspekty pozwalają zrozumieć właściwe implikacje omawianej dyscypliny. Są one tyleż proste, co rewolucyjne: pełzająca utopia medycyny narracyjnej zamierza połączyć pacjentów i ich rodziny, lekarzy i personel medyczny, naukowców i nauczycieli. Planuje narracyjnie powiązać szpitale, laboratoria, przychodnie, gabinety, uczelnie. Chce na nowo spleść społeczeństwo, tak aby nie oddzielano już choroby od zdrowia i umierania od życia. Medycyna narracyjna da się więc sprowadzić do słów, które pragnęlibyśmy przekazać każdemu ciężko choremu. Brzmią one: „Nigdy w chorobie nie będziesz szedł sam".

Utopii tej zagraża nie to, że się nie spełni, lecz to, że spełni się dla nielicznych.

24 Z wcześniejszych prac dodać należy monografię Krystyny Pietrych Co poezji po bólu? Empatyczne przestrzenie lektury (Wydawnictwo UŁ, Łódź 2009), z najświeższych - studium Sebastiana Porzuczka Mapowanie bólu. Lektura - spojrzenie - afekt (Universitas, Kraków 2020). 


\section{Abstract}

\section{Przemysław Czapliński}

ADAM MICKIEWICZ UNIVERSITY (POZNAŃ)

A Caring Utopia

Czapliński discusses the basic definitions of narrative medicine, the historical conditions of the birth of this practice, the concept of narrative circles implied by narrative medicine and their Polish precursors.

\section{Keywords}

narrative medicine, medicine as a system, narrative circles, socialisation of medicine, medical utopia. 